\title{
醬油防徽劑について
}

\section{The Antibiotics for Soy-Film Yeast}

（昭和 27 年 5 月 19 日受理)

$\begin{array}{lll}\text { 山西 昼 石川芳 典 } \\ \text { (Tei Yamanishi) } & \text { (Yoshinori Ishikawa) }\end{array}$

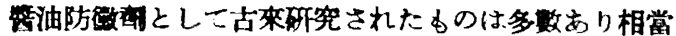
な效果を示したすのとして有機醊，フミン，酸てマイド，

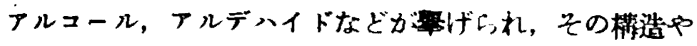
アルキル基の分子量により防效果に大きな筫化を與光 ることが知的れだ。便によく研究されたものでは芥子油 類 (R・NCS) があり, その構造と効力との腊保に一い ての确究するる。近年ではバラオキシ安息香酸のエンテ 几類がとり上げられ，そのエステルを满成するアルコ一

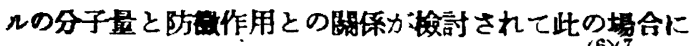

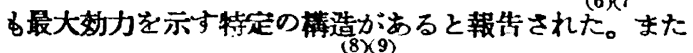
オキシヂフェニールメーテル,オキシヂフェニールエー テルカルボン酸やロダン酶酸エステル, 更に特色ある。 のとしては有機合成色莱や，サリチ几酸，バラオキシ安

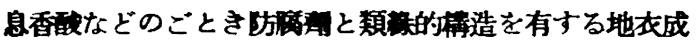
分(フェノールカルボン酸びそのェステル類)を中心

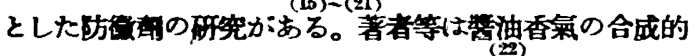
研究に當り多くの類整油香军を得たので,これと開連を

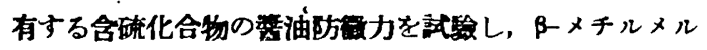

カス゚トエチルメチルケトン $\left(\mathrm{CH}_{3} \mathrm{SCH}_{2} \mathrm{CH}_{2} \mathrm{COCH}_{3}\right)$ 特よ びメチルェチルケトンメチルメルカプトール $\left(\begin{array}{l}\mathrm{CH}_{2} \mathrm{H}_{5} \\ \mathrm{C}_{5}\end{array}\right\rangle \mathrm{C}$ $\left\langle\mathrm{SCH}_{3}\right)$ が 1/5000 以上.の瀿度に於いて 30 日以上防 效果を示すことを知つた。これはれチルケトン類が防 虫氷虫力を有するとい5結果と考六合せて與味ある事蒉 ではあるが，現在㕍く用いられているバラオキシ安息香 酸エステル類に比してその协果少るのは邀撼である。

\section{實驗の部}

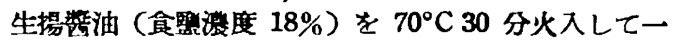

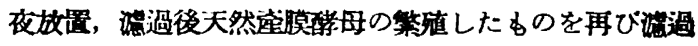
して菑監に供した。容量 $50 \mathrm{cc}$ の角コルベンに叶算量 の菏料と水を添加した繁油を $20 \mathrm{cc}$ 宛探り，棉栓を施し

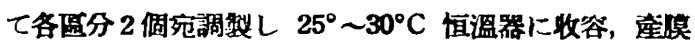
硣母發生狀態を䚈察した。これを再度継返して得た結果 は头の如くであつて表中の數字は湤面全䯏が產脱醉母に よつて灌く㽬はれるに要した日數を示寸。

Table I. Antibiotic action of sulfur-compounds concerning to the soy-flavor.

The number shows their inhibiting period (days) for the soy-film yeast.

$$
\text { Compound \conens. in soy }
$$

Control (water)

Thioglycolic acid

Trioglycol

Thioglycol-pyruvate

Thioglycol-levulinate

a-Phenyl-thioglycol

Methioninol ( $\gamma$-methyl mercapto propyl alcohol)

Methioninol-pyruvate

Methioninol-levulinate

-Methyl mercapto-ethyl alcohol

ß-Methyl mercapto-ethyl pyruvate

B-Methyl mercąpto-ethyl levulinate

$\boldsymbol{\gamma}$-Methyl mercapto-propyl chloride

a-Phenyl- $\beta$-methyl-thioglycol

-Methyl mercapto-ethyl methyl ketone

$\begin{array}{ccc}0.05 \%\left(\begin{array}{c}\text { added } \\ \text { water 50\% }\end{array}\right) & 0.02 \%\left(\begin{array}{c}\text { added } \\ \text { water } 20 \%\end{array}\right) & 0.001 \%\left(\begin{array}{c}\text { added } \\ \text { water 10\% }\end{array}\right) \\ 3 & 5 & 10 \\ 3 & 4 & 10 \\ 4 & 5 & 10 \\ 3 & 3 & 7 \\ 3 & 5 & 9 \\ 3 & 5 & 10 \\ 3 & 4 & 10 \\ 3 & 5 & 10 \\ 3 & 5 & 11 \\ 3 & 5 & 10 \\ 3 & 5 & 10 \\ 3 & 9 & 10 \\ 3 & 4 & 8 \\ 4 & 8 & 13 \\ 30 & 30 & 15\end{array}$


Octyl methyl-thioether

Lauryl methyl-thioether

$\omega$-Methyl mercapto-furfuryl alcohol

Isovaleral-methyl mercaptal

Methyl ethyl ketone methyl mercaptal

Furfural methyl-mercaptal

本研究を指導された小幡教授に厚く謝意を表する。

\section{文南献}

（1）太田清： 梏祭 5, 914-929 (1927).

（2）山时正一：砋造武報 106, 136-139 (1930).

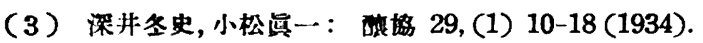

锥造試報 119, 209-217 (1934).

(4) 小林正泌：科工 6, 22-31 (1931).

（5）小林正造：大工研 7,1-43 (1932). 學衍㙝報 7, 601-605 (1932).

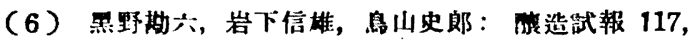
1-5 (1933).

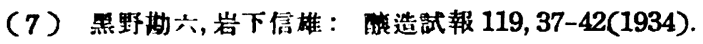

(8) 藤川雨二郎, 中村一郎: 菜學 64, 15-16 (1944).

（9）藤川票二郎, 中村一郎：莱學 64 (甲) 3 (1944).

(10) 藤川雷二郎, 中村一郎：菜學 64, (甲) 54 (1944).

(11) 池田良雄, 横井泰生：笵生試 67, 79-106 (1950).

$\begin{array}{rr}4 & 10 \\ 4 & 10 \\ 13 & 10 \\ 4 & 10 \\ 30 & 10 \\ 5 & 15 \\ & 10\end{array}$

(12) 栗山捨三：九工策 $2,122-130$ (1927).

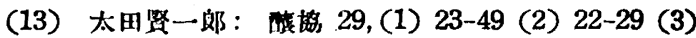
18-29 (1934).

（14）太田㹂一郎：错㙝 31, 127-148 (1936).

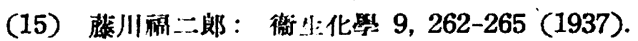

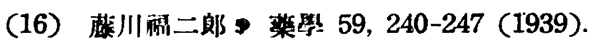

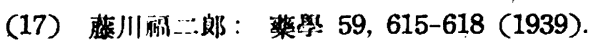

（18）藤川觔二郎，伏見粄一：菜學 61，89-91 (1941).

(19) 藤川解二郎, 中村一郎：策學 62, 459 (1942).

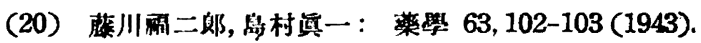

(21) 藤川福二郎, 禹村道一：婪學 65, (2) 519-520 (1945).

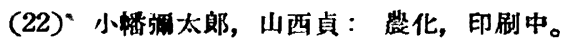

（23）田中安治郎：特許 No. 598 昭和 25 年 2 月 24 日。

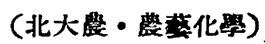

\section{ビタミン $\mathrm{B}_{1}$ の新螢光测定法}

從來のプロムシフン法は $\mathrm{B}_{1}$ とブロムシフンとの反监 によつて生する赤色を比色定量する法であるが，之と 異る條件でプロムシフンを反想させると䝁光物筫が生成 することを認め之を $\mathrm{B}_{1}$ の定最に利用した。その方法は 大の如くである。試料溶液或は標準液を $0 \sim 0.5 \gamma \mathrm{B}_{1} / \mathrm{cc}$.

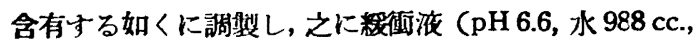
$15 \% \mathrm{NaOH} 15$ cc.; $85 \%$ 燐酸 5 cc., $95 \%$ フルコール $175 \mathrm{cc}$.) 5 cc. と $4 \%$ ブロムシアン水溶液 5 cc. を添加 し 30 分間室溫に放置した後生成した營光を测定し標淮 曲楾か、ら $\mathrm{B}_{1}$ 量を求める。

試料溶液の調製法は從來の方法と同樣に醅素で消化し だ後弱酸で溶出するが, 着色, 混盷或は罃光のむる場合 は狛めZeolite にて處理する。この方法によつて生成す る螢光は時間と共に增大寸るが, 30 分後が最適である。 添加算驗による回收率は 96〜108\% であるが, 微生物法 による定量値とよく一致して居る。この方法の妨害物質 と矠想される Niacin, Niacinamide, Pyridoxine Pyridoxal, 及び Pyridoxamine についても算憸を行い, Pyri- doxal 以外は $\mathrm{B}_{1}$ の 100 倍部共存する場合でも何等妨 害しないことを確めた。Pyridoxal は少量なら餘り問題 とならないが，多望のときは生成する篮光物質のために 相嘗な障害となる。この Pyridoxal による營光は光に 曝すと次第に埥加して行くが， $\mathrm{B}_{1}$ では逆に娍少する。

この方法に於てプロムシアンを添加した後アルカリを 添加することにより Niacinamide が湘定されることは 采知のことであるが，更に Pyridoxine を含有する液に ブロムシアンを加えた後, m-Phenylenediamine を源加 すれはば Pyridoxine の灙度に或程度比例して䖝光物犋が 生成することは興味ある酷察である。但し定量は困難で あると言つている。

以上の如くこの方法はその操作あ进け簢單であり且つ その sensibility もかなり高く, 0〜0.5 $\gamma /$ cc. の範国に あり有効な方法と思わ机るが算驗例が少儿憾みがある。

A new fluorometric determination of thiamine.

Arthur E. Terri, J. Biol. chem., 196, 547 (1952).

(白石) 